\title{
Manual Borehole Drilling as a Cost-Effective Solution for Drinking Water Access in Low-Income Contexts
}

\author{
Pedro Martínez-Santos ${ }^{1, *}$ C , Miguel Martín-Loeches ${ }^{2}$, Silvia Díaz-Alcaide ${ }^{1}$ and Kerstin Danert ${ }^{3}$ \\ 1 Departamento de Geodinámica, Estratigrafía y Paleontología, Universidad Complutense de Madrid, Ciudad \\ Universitaria, 28040 Madrid, Spain; silviadiazalcaide@ucm.es \\ 2 Departamento de Geología, Geografía y Medio Ambiente, Facultad de Ciencias Ambientales, Universidad \\ de Alcalá, Campus Universitario, Alcalá de Henares, 28801 Madrid, Spain; miguel.martin@uah.es \\ 3 Ask for Water GmbH, Zürcherstr 204F, 9014 St Gallen, Switzerland; kerstin.danert@ask-for-water.ch \\ * Correspondence: pemartin@ucm.es; Tel.: +34-659-969-338
}

Received: 7 June 2020; Accepted: 7 July 2020; Published: 13 July 2020

\begin{abstract}
Water access remains a challenge in rural areas of low-income countries. Manual drilling technologies have the potential to enhance water access by providing a low cost drinking water alternative for communities in low and middle income countries. This paper provides an overview of the main successes and challenges experienced by manual boreholes in the last two decades. A review of the existing methods is provided, discussing their advantages and disadvantages and comparing their potential against alternatives such as excavated wells and mechanized boreholes. Manual boreholes are found to be a competitive solution in relatively soft rocks, such as unconsolidated sediments and weathered materials, as well as and in hydrogeological settings characterized by moderately shallow water tables. Ensuring professional workmanship, the development of regulatory frameworks, protection against groundwater pollution and standards for quality assurance rank among the main challenges for the future.
\end{abstract}

Keywords: appropriate technologies; developing regions; excavated well; food security; human right to water; improved water sources.

\section{Introduction}

The United Nations recognize access to drinking water and sanitation both as human rights and as prerequisites for the fulfilment of several other human rights [1]. Water supplies must be physically accessible, sufficient in quantity, safe in terms of quality, available when needed, acceptable from the organoleptic standpoint, and affordable for everyone. While this ideal has been implemented in many industrialized countries, universal water access is yet to be achieved in many parts of the world, with rural areas significantly lagging behind [2]. This is often due to the absence of economic resources, technology and trained technicians, and generally represents a greater challenge in rural areas.

Appropriate technologies may contribute to the wellbeing of human communities by providing an intermediate solution between unimproved and improved water sources. Appropriate technologies are tools that allow individuals and communities to meet their needs with limited reliance on external industry-based processes. This definition encompasses a common set of features, including small scale, labor intensiveness and local control. Often described as "the minimum level of technology that can meet the needs of a given community during a given time", appropriate technologies are typically utilized within the specific conditions of the areas where they are suited, and promote self-sufficiency on the part of those who use them. By their own nature, appropriate technologies are suited, but not limited, to middle- and low-income settings [3]. Appropriate technologies have been developed for a wide range of fields, such as building, energy and agriculture [4-6]. The same applies to the water 
and sanitation sector [6]. Since aquifers provide a reliable source of drinking water for communities across the world, groundwater has its own share of appropriate technologies. Take, for instance, artificial aquifers [7], treadle pumps [8], VLOM (village-level operation and maintenance) pumps [9] and manual borehole drilling [10].

This paper deals specifically with manual drilling. A clear conceptual distinction exists between manual drilling and excavation (Table 1). Manually drilled boreholes are made by replicating mechanical drilling methods by hand, not by pick and shovel. As a result, manual boreholes are small in diameter (typically 70 to $400 \mathrm{~mm}$ ). Much like mechanized boreholes, they can be sealed and cased, and equipped with gravel packs, sanitary seals and submersible pumps. Furthermore, manual boreholes are often deeper than excavated wells, and thus tap deeper aquifers. This can result in greater reliability of the water point when water tables fall. If the boreholes are properly sealed, they provide better protection from surface contamination.

Manual drilling methods have been known for a long time [11]. Sludging, for instance, is considered a traditional technique in countries like India or Bangladesh [12], while percussion was already used by the Chinese millennia ago [13]. Hand drilling is a forgotten art in industrialized countries, where it has been replaced by automated methods. Manual drilling has, however, experienced a revolution in the last two decades, partially fueled by development projects across Africa, Asia and Latin America [14]. Over 100,000 hand boreholes have been drilled in India, to go with another 100,000 in Vietnam and Nepal, 30,000 in Nigeria, 16,000 in Niger and over 1000 in Chad and the Democratic Republic of Congo [12,15,16]. Manually drilled boreholes provide a significant proportion of drinking water in Bangladesh, India and Nepal [14], while an estimated 650,000 people drink from manually drilled boreholes in the Democratic Republic of Congo [16] and up to 5 million people across the Lagos region, Nigeria [17]. Manual drilling is also relatively widespread in countries like Bolivia, Madagascar, Nicaragua and Senegal, and has become a flourishing business in areas of Bangladesh, Nigeria, Niger and Sudan $[14,17,18]$.

While not exempt from shortcomings, manually drilled boreholes have proven an opportunity for social and economic development. The main reasons explaining the expansion of manual drilling are affordability, suitable geology and hydrogeology, and a lack of alternatives. The only prerequisite in both rural and urban contexts is the availability of technical expertise and equipment. In urban and peri-urban contexts of developing countries, many wealthier households are investing in their own water supplies due to a lack of a reliable piped water supply, or no piped water supply services as all. In rural areas, development projects and communities are investing in manual boreholes, because these are considerably cheaper than mechanized boreholes.

The academic literature has seldom been concerned with manual drilling. Based on grey literature, technical reports and the hands-on experience of the authors, this paper begins by presenting the social and economic context for manual drilling, together with the main drilling techniques. The focus then shifts to a comparison between manual drilling and other groundwater access methods (i.e., excavated wells and mechanized boreholes). Finally, the successes and challenges faced by the manual drilling sector are appraised in the context of the need to achieve universal water access. 
Table 1. Key definitions and concepts [19].

\begin{tabular}{|c|c|c|}
\hline Category & Term & Definition \\
\hline \multirow{4}{*}{$\begin{array}{l}\text { Wells and } \\
\text { boreholes }\end{array}$} & Borehole & $\begin{array}{l}\text { A narrow shaft bored in the ground for the purpose of extracting } \\
\text { groundwater. Boreholes are cased, gravel packed and equipped with } \\
\text { a pump and wellhead protection. }\end{array}$ \\
\hline & Manual borehole & $\begin{array}{l}\text { A borehole drilled by manual means, replicating the work of } \\
\text { a mechanical rig by hand. Typically less than } 50 \mathrm{~m} \text { deep, with } \\
\text { a casing diameter of } 70 \text { to } 400 \mathrm{~mm} \text {. May be gravel packed and } \\
\text { equipped with a pump and wellhead protection. }\end{array}$ \\
\hline & $\begin{array}{l}\text { Mechanized } \\
\text { borehole }\end{array}$ & $\begin{array}{l}\text { A borehole drilled by means of a mechanical rig. It may be hundreds } \\
\text { of meters deep. }\end{array}$ \\
\hline & $\begin{array}{l}\text { Excavated well, } \\
\text { dug well, well }\end{array}$ & $\begin{array}{l}\text { A large diameter hole in the ground used for the purpose of } \\
\text { extracting groundwater. Typically dug with peak and shovel. It may } \\
\text { be lined with concrete or bricks and equipped with a wellhead for } \\
\text { protection. Generally less than } 20-30 \text { m deep. }\end{array}$ \\
\hline \multirow{4}{*}{ Pumps } & Commercial pump & $\begin{array}{l}\text { A commercially available pump used to extract groundwater from } \\
\text { a borehole. Most standard pumps require casing diameters in excess } \\
\text { of } 200 \mathrm{~mm} \text {. Yields are variable. }\end{array}$ \\
\hline & $\begin{array}{l}\text { Factory-made hand } \\
\text { pump }\end{array}$ & $\begin{array}{l}\text { A pump powered by hand. If the aquifer is sufficiently productive, } \\
\text { yields are limited by the pumping capacity of a human being. }\end{array}$ \\
\hline & $\begin{array}{l}\text { Electric } \\
\text { submersible pump }\end{array}$ & $\begin{array}{l}\text { A pump powered by electricity from the grid, using gasoil or solar } \\
\text { energy. If the aquifer is sufficiently productive, yields may exceed } \\
\text { those from hand and locally made pumps. }\end{array}$ \\
\hline & $\begin{array}{l}\text { Locally made } \\
\text { handpump }\end{array}$ & $\begin{array}{l}\text { A non-commercial hand pump. Typically made with inexpensive } \\
\text { local materials and powered by human action. Less durable than } \\
\text { a factory-made hand pump, but easier to make and cheaper to fix. } \\
\text { The flow rate is similar. }\end{array}$ \\
\hline
\end{tabular}

\section{Social and Economic Context}

The now-superseded Millennium Development Goals aimed at halving the number of people without sustainable access to safe drinking water by year 2015. This led to unprecedented efforts to improve the living conditions of millions of people. The United Nations declared the goal to be accomplished ahead of schedule [20,21]. This claim was, however, refuted by a number of authors, who argued that success had been measured in terms of unsuitable benchmarks, and that, although progress had definitely been made, there was still a long way to go [22]. Indeed, by placing a heavy emphasis on "improved water sources", global figures disregarded the fact that many of these fail to render a reliable and affordable service. Furthermore, it has been shown that sources considered to be improved do not always provide good quality water [23,24].

The Sustainable Development Goals use a series of more sophisticated benchmarks, and distinguish between "safely managed", "basic", "limited", "unimproved" and "surface" water supplies [25]. The notion of "safely managed" supplies refers to improved sources located on premises, available when needed and free of fecal and priority contamination. In contrast, "basic" water supplies refers to improved sources located away from premises where collection time is not more than 30 minutes for a roundtrip, including queuing. It is estimated that $71 \%$ of the world's population currently has access to safely managed drinking water services [26], although there are notable differences between urban and rural areas ( $85 \%$ vs $55 \%$ ). Current estimates suggest that over $88 \%$ of the population has access to at least a basic supply ( $80 \%$ rural and $95 \%$ urban). It is however true that widespread water quality testing is yet to be achieved [27]. Practical challenges notwithstanding, decentralized techniques for testing and treatment could provide a welcome solution in the coming years [28,29].

For many sector professionals, political leaders and households, an ideal water supply is one that is safely piped into the home. However, this kind of service currently remains unfeasible in many parts 
of the world. In some cases it could even be unsuitable due to environmental considerations. Thus, point sources remain the standard in much of urban and rural Sub-Saharan Africa, where groundwater plays an essential role in underpinning the daily existence of millions of people (Figure 1). Take, for instance, Burkina Faso, Central African Republic, Chad, Ethiopia, Nigeria, South Sudan and Uganda, where aquifers are the main water source for $70 \%$ to $90 \%$ of domestic water uses [30]. This is mostly because groundwater is nearly ubiquitous in many regions, and because it is naturally better protected from pollution and not as dependent on recent rainfall as surface water [31].

Community hand pumps are an archetypal example of groundwater-based communal supplies. Simple and cost-effective, hand pumps are installed directly on boreholes or hand-dug wells, and allow users to extract groundwater manually, or increasingly, with solar-powered systems [32,33]. Maintenance is supposed to be simple, which explains why hand pumps have been promoted as the technology of choice four decades. Nevertheless, experience shows that hand pumps are not promptly repaired when they break down. Take, for instance, the case of rural Sub-Saharan Africa, where surveys carried out across several countries revealed that approximately one third of the existing hand pumps were non-functional [34]. A number of reasons have been associated with non-functionality, including age, distance from a major urban center and the absence of user fees [35]. The quality of work conducted during siting and drilling and installation, and the extent, qualit, and oversight of operations and maintenance post-construction are also matters of concern [36].

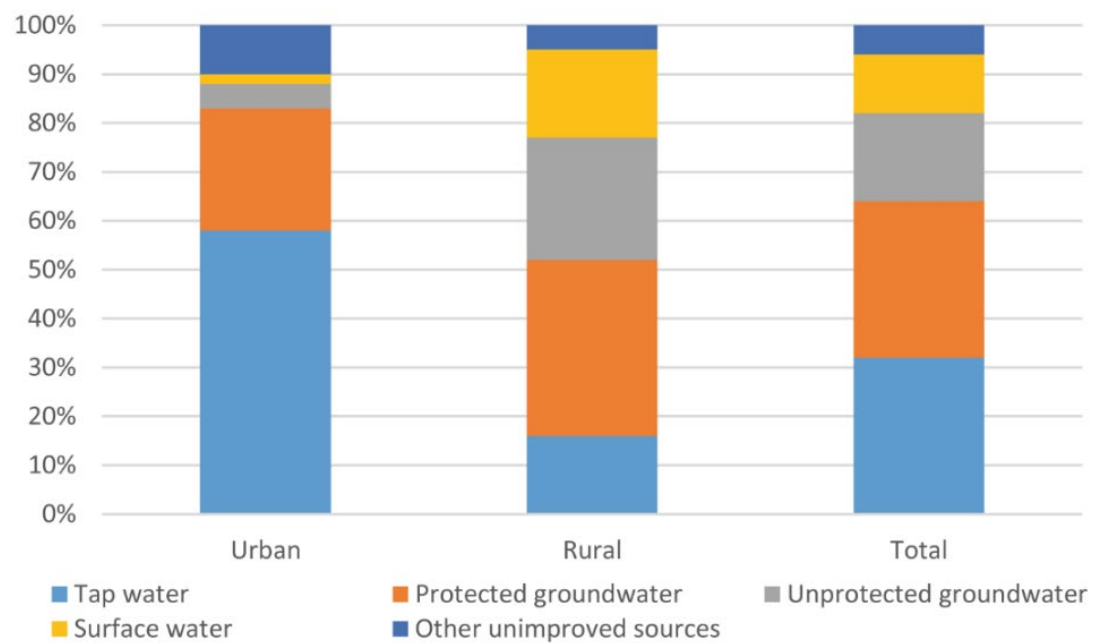

Figure 1. Estimates of sources of drinking water sources in Sub-Saharan Africa [37].

A major limitation with community-based infrastructures, more specifically boreholes, is cost. Accurate economic data is difficult to find, partly because there are few systematic studies and partly because the available information is fragmented and non-standardized (Table 2). Furthermore, borehole cost depends on several factors, including geological constrains, depth, width, equipment, mobilization and fuel costs, as well as commercial profit. This means that what works for a given user or location may not work for another, and thus, that the amounts are not necessarily comparable. Some estimates however exist. For instance, the cost of drilling a mechanized borehole in Sub-Saharan Africa varies between $\$ 2000$ and $\$ 500,000$ ( $\$ 120$ to $\$ 1270$ per meter), normally ranging between $\$ 5000$ and $\$ 15,000[38,39]$. These figures are prohibitive for several hundred million people, who cannot afford these costs. In this context, any alternatives that reduce the costs of accessing groundwater are worth considering. Manual drilling has sometimes been advocated as a cost-effective solution, largely because, as shown later, manual boreholes are considerably more affordable than those provided through mechanized drilling. 
Table 2. Manual drilling in selected countries [14].

\begin{tabular}{|c|c|c|c|c|c|}
\hline Country & $\begin{array}{l}\text { Estimated } \\
\text { Number }\end{array}$ & Location & Techniques & Date & Costs \\
\hline Bangladesh & Millions & $\begin{array}{c}\text { Most } \\
\text { sedimentary } \\
\text { basins }\end{array}$ & Sludging & 1900 s to date & $\$ 1$ per meter \\
\hline Bolivia & 30,000 & & EMAS, Baptist & 1983 to date & $\$ 300$ \\
\hline Chad & Thousands & Central Chad & & 1960s to date & \\
\hline $\begin{array}{l}\text { Democratic } \\
\text { Republic of } \\
\text { Congo }\end{array}$ & $>1000$ & $\begin{array}{l}\text { West, south and } \\
\text { some in the east }\end{array}$ & $\begin{array}{l}\text { Jetting, village } \\
\text { drill }\end{array}$ & 2007 to date & \\
\hline Kenya & 10,000 & Various regions & $\begin{array}{l}\text { Augering, } \\
\text { sludging, } \\
\text { percussion, } \\
\text { Baptist }\end{array}$ & 1979 to date & $\begin{array}{l}\$ 4000 \text { (augered } \\
\text { to } 40 \mathrm{~m} \text { ) }\end{array}$ \\
\hline India & Millions & Various regions & $\begin{array}{l}\text { Sludging, } \\
\text { jetting, } \\
\text { augering }\end{array}$ & $\begin{array}{l}\text { Indigenous } \\
\text { technology }\end{array}$ & \\
\hline Madagascar & 12,000 & $\begin{array}{l}\text { East and west } \\
\text { coast (driven } \\
\text { wells), } \\
\text { throughout } \\
\text { the country } \\
\text { (jetting, } \\
\text { rota-sludge) }\end{array}$ & $\begin{array}{l}\text { Driven wells, } \\
\text { jetting, } \\
\text { rota-sludge }\end{array}$ & $\begin{array}{l}\text { 1960s to date } \\
\text { (driven); early } \\
2000 \text { s to date } \\
\text { (jetting, } \\
\text { rota-sludge) }\end{array}$ & $\begin{array}{c}\$ 35 \text { to } \$ 50 \\
\text { (driven wells); } \\
\$ 1000 \text { to } \$ 3000 \\
\text { (<30 m depth) }\end{array}$ \\
\hline Nepal & $>100,000$ & Terai (lowland) & Sludging & 1950s to date & $\$ 20-\$ 450$ \\
\hline Niger & 16,000 & $\begin{array}{l}\text { Maradi and } \\
\text { Zinder regions }\end{array}$ & $\begin{array}{l}\text { Augering, } \\
\text { jetting, } \\
\text { rota-sludge, } \\
\text { percussion }\end{array}$ & $\begin{array}{l}1900 \mathrm{~s} \\
\text { (irrigation; } 2005 \\
\text { to date }\end{array}$ & \\
\hline Nigeria & 30,000 & $\begin{array}{l}\text { At least } 27 \text { of } \\
\text { the } 36 \text { states }\end{array}$ & $\begin{array}{l}\text { Jetting, } \\
\text { augering, } \\
\text { percussion, } \\
\text { Baptist }\end{array}$ & $\begin{array}{l}\text { Early 1980s to } \\
\text { date }\end{array}$ & $\$ 2500$ or less \\
\hline Senegal & $>4000$ & Various regions & $\begin{array}{l}\text { Augering, } \\
\text { jetting, } \\
\text { percussion, } \\
\text { rota-jetting }\end{array}$ & 1991 to date & $\$ 1600$ to $\$ 2000$ \\
\hline Uganda & $<1000$ & $\begin{array}{l}\text { Lake Victoria, } \\
\text { west, north and } \\
\text { south }\end{array}$ & $\begin{array}{l}\text { Rotary-sludge, } \\
\text { rotary jetting, } \\
\text { Baptist }\end{array}$ & $\begin{array}{l}\text { Late } 1980 \text { s to } \\
\text { early } 1990 \text { s; } \\
\text { pilot projects } \\
\text { from } 1998 \text { to } \\
2013 .\end{array}$ & \\
\hline Vietnam & $>100,000$ & & Sludging & $1980 \mathrm{~s}$ & \\
\hline
\end{tabular}

\section{Manual Drilling Methods}

As shown in Figure 2, four major hand-drilling techniques exist. These are augering, sludging, jetting and percussion [40]. Each presents various versions, which generally stem from their adaptation to different regional contexts $[12,41]$. There are also hybridizations, such as jetting-sludging and percussion-sludging. Each method presents specific advantages and disadvantages. For instance, augering is conceptually simple and easy to learn. It allows for rapid drilling in soft materials, but becomes a challenge at greater depths and when operating below the water table. On the other hand, percussion is relatively slow, but it is effective in terms of drilling below the water table and can break 
through consolidated rock. Thus, the potential to facilitate water access is different with each technique (Table 3).

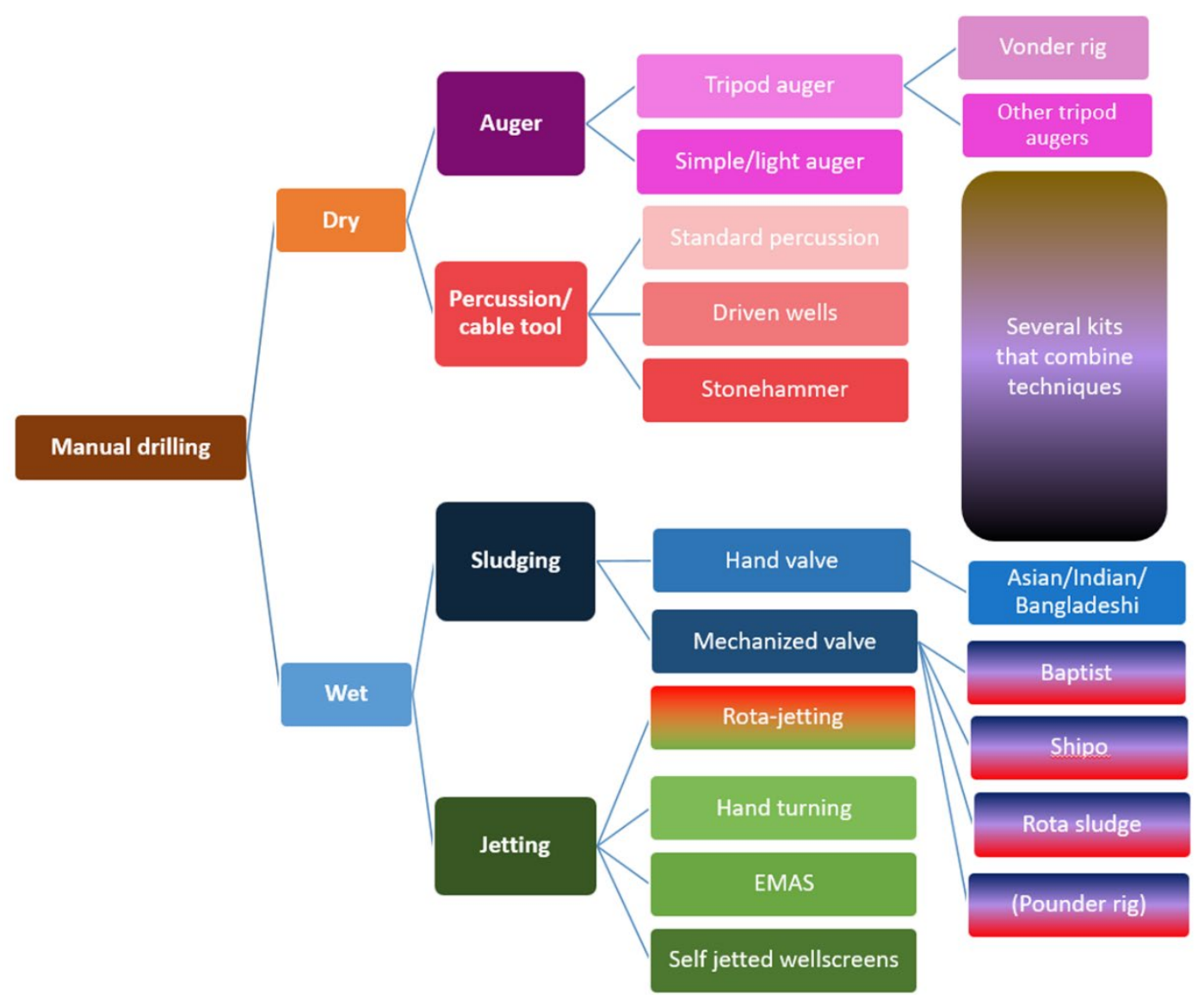

Figure 2. Manual drilling family tree [41].

Table 3. Suitability and limitations of manual drilling methods.

\begin{tabular}{|c|c|c|c|c|}
\hline Technique & Material & Advantages & Disadvantages & $\begin{array}{c}\text { Drilling } \\
\text { Range }(\mathrm{m})\end{array}$ \\
\hline Augering & $\begin{array}{l}\text { Unconsolidated } \\
\text { sediments }\end{array}$ & $\begin{array}{l}\text { Simple, cheap, fast } \\
\text { in soft sediments }\end{array}$ & $\begin{array}{l}\text { Limited to soft materials } \\
\text { and to relatively small } \\
\text { depths. May be } \\
\text { problematic when } \\
\text { drilling below the water } \\
\text { table. }\end{array}$ & $15-20$ \\
\hline Jetting & $\begin{array}{l}\text { Unconsolidated } \\
\text { sediments }\end{array}$ & $\begin{array}{l}\text { Fast in soft } \\
\text { sediments }\end{array}$ & $\begin{array}{c}\text { Potentially expensive } \\
\text { equipment. A large } \\
\text { volume of water is } \\
\text { needed. }\end{array}$ & $25-50$ \\
\hline $\begin{array}{l}\text { Percussion and } \\
\text { bailing }\end{array}$ & $\begin{array}{l}\text { Unconsolidated } \\
\text { sediments and soft } \\
\text { weathered rock }\end{array}$ & $\begin{array}{l}\text { Can drill through } \\
\text { moderately hard } \\
\text { rocks. May be } \\
\text { coupled with } \\
\text { sludging. }\end{array}$ & $\begin{array}{l}\text { Slower and potentially } \\
\text { more expensive than } \\
\text { other methods. }\end{array}$ & $25-50$ \\
\hline Sludging & $\begin{array}{l}\text { Unconsolidated } \\
\text { sediments }\end{array}$ & $\begin{array}{l}\text { Ease of use. Fast in } \\
\text { soft sediments. }\end{array}$ & Limited to soft materials. & $25-50$ \\
\hline
\end{tabular}




\subsection{Augering and Bailing}

Augering consists of driving a drilling bit into the ground by rotating a handle at the surface. Handle and bit are linked by means of a sequence of extendable rods, typically made of steel. The bit is equipped with a shaft that collects material from the bottom of the hole. As the bit fills up, the auger is removed and emptied. The process is repeated until the desired depth is reached. A temporary casing may keep the hole from collapsing, particularly when working below the water table.

This method can quickly drill shallow wells through soft formations. It is easy to learn and conceptually straightforward. Furthermore, the equipment is cheap and simple to build. However, augering presents some shortcomings. It is of limited value in highly permeable sediments such as coarse gravels, which restrict its potential in theoretically favourable terrains such as alluvial plains. Moreover, drilling becomes slower and more difficult with depth, and it can be difficult to keep boreholes straight. Hence, augering is best used in combination with other drilling techniques.

Augered boreholes rarely exceed $20-25 \mathrm{~m}$. A borehole may be drilled by just one or two people in some cases, but drilling crews are typically made up of four to six people. A complete borehole can be made in less than one week.

\subsection{Percussion and Bailing}

Percussion is possibly the oldest-known drilling technique. A heavy bit is tied to a cable, which in turn runs through a pulley attached to a tripod above the hole. The cable is pulled to lift the bit and then released to let it fall, thus breaking the rock. Loosened material falling to the bottom of the borehole is removed with a bailer equipped with a no-return valve. Thus, it can be loaded with water and rock can be loosened by moving it up and down. The bailer process entails removing the bit from the hole, which is carried out every few strokes.

By its own nature, percussion is useful in hardened materials such as gravels or boulders. Depths in excess of $30 \mathrm{~m}$ can often be achieved with a small up-front investment and relatively little technical skill. On the other hand, percussion is slow in comparison with the other methods. Furthermore, bailing becomes cumbersome as the borehole gets deeper. This is the main reason why percussion is sometimes combined with water circulation. By mimicking the behaviour of a mechanical rig, debris from the bottom may be removed faster [42].

\subsection{Sludging}

Sludging represents an advancement over augering and percussion because there is no need to stop the drilling process to remove debris from the bottom of the hole. Sludging needs the borehole to be full of water at all times, using water circulation to bring the loosened bits to the surface.

Sludging can be coupled with percussion by incorporating an improved drilling tool. This comprises a heavy drilling bit, a hand- or foot-valve, a series of hollow tubes, and an outlet. The drilling tool is lifted and allowed to fall repeatedly into the hole by pulling and releasing the rope. The valve opens on the down stroke, allowing water and sediment from the bottom of the hole into the hollow inside of the tool. Conversely, it closes on the upstroke, forcing the mix to move upwards. As the fluid reaches the outlet it is released into a mud pit. The pit acts as a decanter wherefrom water flows back into the hole. Thickening agents, such as polymers or bentonite, may be used to facilitate the rise of drilling cuts to the surface, as well as to prevent the hole from collapsing. At the local scale, these are sometimes replaced by clay or even cow dung.

A drilling crew is typically made up of six to ten people, who take turns to pull the rope, operate the tool and rest. Wells drilled by combining sludging and percussion usually range between 25 and $50 \mathrm{~m}$, although depths in excess of $100 \mathrm{~m}$ have been obtained in favourable regions of Bolivia [43]. Drilling time normally fluctuates between a few days and a few weeks, depending mostly on the geological context. The combination of percussion and sludging is useful in a wide variety of 
geological formations, ranging from soft materials such as alluvial sediments or weathering products, to consolidated rocks, such as sandstone or laterite. Its applicability in fresh crystalline rocks is limited.

Rota-sludge is a variant of sludging. A wooden structure, consisting of two vertical poles with an axle in between, is built near the hole. This serves as a support for a lever mechanism, which is used to move the drilling tool up and down. An arm attached to the drill pipe allows for it to be rotated at the moment it hits the bottom of the hole. Much like percussion sludging, rota-sludge uses a no-return valve to lift the water column thought the inside of the drilling tool, squirting the spoils into a mud pit. Rota-sludge is typically limited to depths of about $35 \mathrm{~m}$, although greater depths are possible under favourable conditions [44].

\subsection{Jetting}

Jetting consists of injecting pressurized water into the borehole. The injection is carried out through a series of hollow tubes connected to the drilling bit. This erodes the bottom of the hole, making it deeper over time. In compact materials, injection can be enhanced by fitting a rotary arm, so that the drilling bit can be turned from the surface.

Hydraulic pressure keeps the borehole open and helps to evacuate the spoils through the space left between the drilling pipe and the sides. Water may be thickened by adding a suitable amount of bentonite, clay or drilling polymers. This presents the additional advantage of sealing the walls, thus limiting water and pressure losses.

Water coming out flows into a mud pit, where the drilling cuts are allowed to decant before the water is re-circulated into the hole. Water losses are minimal if the pit is lined, but jetting is water-intensive. A nearby water source, such as a dug well, a stream or a river, is required. Jetting also needs a powered pump.

Jetting is typically used in soft material such as unconsolidated sedimentary formations. Boreholes drilled with this technique often reach about $30 \mathrm{~m}$, although depths of 50-60 m have been obtained [39].

\section{Manual Boreholes Versus other Technical Solutions}

Manual drilling is a discipline in its own right. It is conceptually different from digging and presents a series of specific features that set it apart from mechanical drilling. Hence, its potential can be appraised in terms of relative strengths and weaknesses (Table 4).

For the purpose of the ensuing discussions, it should be noted that water requirements in developing contexts are lower than in industrial societies. Domestic water demands are frequently estimated at 20 liters per person and day, although this figure can vary [45]. One communal hand pump yields around $1 \mathrm{~m} 3 / \mathrm{h}$, so it is sufficient to meet the daily needs of 300 to 500 people. In general, securing access is the priority, while attention to water quality is more limited [46].

The human right to water refers specifically to drinking supplies, but also provides for subsistence agriculture. This means that boreholes may be considered productive even when yield is modest compared to other standards. As a rule of thumb, flow rates in excess of $3-4 \mathrm{~m}^{3} / \mathrm{h}$ may be enough to underpin small-scale community orchards, while yields below $2-3 \mathrm{~m}^{3} / \mathrm{h}$ are often insufficient. The aquifer's hydrodynamic parameters thus play an important role, regardless of the technique of choice $[47,48]$. 
Table 4. Comparison between excavated wells, manual boreholes and mechanical well drilling (partially based on comparative frameworks from the manual drilling literature [18]).

\begin{tabular}{|c|c|c|c|}
\hline Aspect & Excavated Wells & Manual Boreholes & Mechanized Boreholes \\
\hline Business investment & $\begin{array}{l}\text { Very low-digging tools } \\
\text { typically amount to less } \\
\text { than } \$ 50 .\end{array}$ & $\begin{array}{l}\text { Low-between } \$ 500 \text { and } \\
\$ 2000 \text {, depending on } \\
\text { geographical and } \\
\text { technical considerations. }\end{array}$ & $\begin{array}{l}\text { Very high-a drilling rig } \\
\text { costs hundreds of } \\
\text { thousands of dollars. }\end{array}$ \\
\hline Drilling cost & $\begin{array}{l}\text { Very low }(\approx 0) \text { if the user } \\
\text { digs the well of if labor } \\
\text { exchange is involved. } \\
\text { More expensive if labor } \\
\text { is hired or if well is } \\
\text { lined/protected } \\
(\$ 50-\$ 400) .\end{array}$ & $\begin{array}{l}\text { Low- } \$ 5 \text { to } \$ 25 \text { per } \\
\text { meter for a borehole } \\
\text { equipped with grid, } \\
\text { gravel pack and } \\
\text { well-head protection. }\end{array}$ & $\begin{array}{l}\text { High- } \$ 80 \text { to } \$ 1000 \text { per } \\
\text { meter (in extreme cases) } \\
\text { for a borehole equipped } \\
\text { with grid, gravel pack } \\
\text { and well-head } \\
\text { protection. }\end{array}$ \\
\hline $\begin{array}{l}\text { Cost of extraction } \\
\text { devices }\end{array}$ & $\begin{array}{l}\text { Negligible if water is } \\
\text { extracted with buckets. } \\
\text { Between } \$ 300-\$ 4000 \text { if } \\
\text { commercial pumps are } \\
\text { used. }\end{array}$ & $\begin{array}{l}\text { Negligible if water is } \\
\text { extracted with } \\
\text { a locally-made hand } \\
\text { pump. Between } \\
\$ 300-\$ 4000 \text { if commercial } \\
\text { pumps are used. }\end{array}$ & $\begin{array}{l}\text { Commercial pump } \\
\text { almost always used } \\
(\$ 300-\$ 4000) .\end{array}$ \\
\hline Depth & $\begin{array}{l}\text { Up to } 20-30 \mathrm{~m} \text { (may be } \\
\text { considerably deeper } \\
\text { occasionally). Collapse } \\
\text { risk when digging below } \\
\text { the water table in } \\
\text { unconsolidated } \\
\text { sediments. }\end{array}$ & $\begin{array}{l}\text { Average depths usually } \\
\text { range between } 25 \text { and } 50 \\
\mathrm{~m} \text {. May exceed } 100 \mathrm{~m} \text { in } \\
\text { very favourable } \\
\text { conditions. }\end{array}$ & $\begin{array}{l}\text { Up to several hundred } \\
\text { meters deep. May } \\
\text { capture groundwater at } \\
\text { great depths. }\end{array}$ \\
\hline $\begin{array}{l}\text { Accessibility of } \\
\text { technology for users }\end{array}$ & $\begin{array}{l}\text { Widely accessible. Users } \\
\text { may dig their own wells. }\end{array}$ & $\begin{array}{l}\text { Users may drill their } \\
\text { own boreholes with } \\
\text { some guidance. } \\
\text { Small-scale enterprises } \\
\text { can also provide } \\
\text { the service. }\end{array}$ & $\begin{array}{l}\text { Users always need to } \\
\text { rely on professional } \\
\text { drilling enterprises. }\end{array}$ \\
\hline Time and labour & $\begin{array}{c}\text { Very laborious and } \\
\text { time-consuming. Wells } \\
\text { usually take weeks to } \\
\text { dig. }\end{array}$ & $\begin{array}{l}\text { Under very favourable } \\
\text { conditions boreholes can } \\
\text { be drilled in one day and } \\
\text { installed on } \\
\text { the following one. In } \\
\text { most settings, boreholes } \\
\text { may take a few weeks to } \\
\text { drill. }\end{array}$ & $\begin{array}{l}\text { Typically quick. In some } \\
\text { cases boreholes can be } \\
\text { drilled, equipped and } \\
\text { developed within two or } \\
\text { three days. However, } \\
\text { transporting } \\
\text { a mechanized rig to } \\
\text { the site may be } \\
\text { time-consuming (even } \\
\text { unfeasible). }\end{array}$ \\
\hline Geological constrains & $\begin{array}{l}\text { Can make it through } \\
\text { hard rock, but will take } \\
\text { a long time (weeks to } \\
\text { years in extreme cases). } \\
\text { Digging is often } \\
\text { restricted to the end of } \\
\text { the dry season. }\end{array}$ & $\begin{array}{l}\text { Typically suited to soft, } \\
\text { unconsolidated } \\
\text { sediments, but some } \\
\text { methods (i.e., percussion } \\
\text { and variations of } \\
\text { percussion) may traverse } \\
\text { consolidated rocks of } \\
\text { medium hardness } \\
\text { (sandstone, laterite). Can } \\
\text { drill at any time of } \\
\text { the year. }\end{array}$ & $\begin{array}{l}\text { Usable under most } \\
\text { geological conditions at } \\
\text { any time of the year. }\end{array}$ \\
\hline
\end{tabular}


Table 4. Cont.

\begin{tabular}{|c|c|c|c|}
\hline Aspect & Excavated Wells & Manual Boreholes & Mechanized Boreholes \\
\hline Yield & $\begin{array}{l}\text { Dependent on diameter, } \\
\text { extraction device (i.e., } \\
\text { buckets or pump). In } \\
\text { some cases several } \\
\text { people can extract water } \\
\text { simultaneously. } \\
\text { Typically } 0.5-4 \mathrm{~m}^{3} / \mathrm{h} \text {. }\end{array}$ & $\begin{array}{c}\text { Dependent on extraction } \\
\text { device. Typically } \\
0.5-1.2 \mathrm{~m}^{3} / \mathrm{h} \text { for hand } \\
\text { pumps, and } 1-4 \mathrm{~m}^{3} / \mathrm{h} \\
\text { with powered pumps. }\end{array}$ & $\begin{array}{l}\text { Dependent on extraction } \\
\text { device. Typically } \\
0.5-1.2 \mathrm{~m}^{3} / \mathrm{h} \text { for hand } \\
\text { pumps. Several } \\
\text { hundred } \mathrm{m}^{3} / \mathrm{h} \text { with } \\
\text { a powered pump (subject } \\
\text { to hydrogeological } \\
\text { conditions). }\end{array}$ \\
\hline Frequent hazards & $\begin{array}{l}\text { Collapses and materials } \\
\text { dropping into the hole } \\
\text { during construction. } \\
\text { Also prone to } \\
\text { contamination and } \\
\text { drying due to } \\
\text { shallowness. Nearby } \\
\text { contamination sources } \\
\text { can compromise } \\
\text { supplies. }\end{array}$ & $\begin{array}{l}\text { Insufficient technical } \\
\text { expertise leading to poor } \\
\text { borehole construction or } \\
\text { to the loss of the borehole } \\
\text { during construction. } \\
\text { Nearby contamination } \\
\text { sources can compromise } \\
\text { supplies. }\end{array}$ & $\begin{array}{l}\text { Combed or inclined } \\
\text { boreholes. Contractor } \\
\text { ill-will or insufficient } \\
\text { technical expertise } \\
\text { leading to poor borehole } \\
\text { construction. Nearby } \\
\text { contamination sources } \\
\text { can compromise } \\
\text { supplies. }\end{array}$ \\
\hline $\begin{array}{l}\text { Suitability for } \\
\text { consumption }\end{array}$ & $\begin{array}{c}\text { Only protected wells } \\
\text { qualify as improved } \\
\text { water sources. }\end{array}$ & $\begin{array}{l}\text { Qualify as improved } \\
\text { water sources if } \\
\text { adequately protected. }\end{array}$ & $\begin{array}{l}\text { Qualify as improved } \\
\text { water sources if } \\
\text { adequately protected. }\end{array}$ \\
\hline
\end{tabular}

\subsection{Manual Boreholes Versus Mechanized Boreholes}

The comparison between manual boreholes and mechanized boreholes can be carried out based on a number of features. These include affordability, accessibility, social value and versatility. Affordability is frequently quoted as the main advantage of manual boreholes. Based on the experience of fifteen different countries, [14] explains that the cost of a manual borehole in most developing countries represents $10-25 \%$ of that of a mechanized borehole. Cost estimates provided by this author range from less than $\$ 50$ (Madagascar, Nepal) to around $\$ 4000$ per borehole (Kenya, Guinea, Mauritania). These findings are consistent with other sources. Analyses carried out in rural areas of Southern Mali conclude that costs fluctuate with a number of variables, including lithology, depth, drilling time, wages and pump type [49]. Costs depend chiefly on wages, that is, on whether the borehole is drilled by a professional crew or by the beneficiaries themselves. The way in which the borehole is equipped-in particular, the pump type and the surrounding infrastructure-also constrains cost to a large extent.

This is best understood with an example. Consider a $200 \mathrm{~mm}$ diameter, $30 \mathrm{~m}$ deep manual borehole drilled by sludging and percussion through laterite, clay and sandstone in Southern Mali. Assuming that this borehole were to be drilled by salaried workers, and equipped with a factory-produced hand pump, the final cost at current market prices would be in the order of $\$ 1200$. In contrast, the cost would drop to $\$ 200$ if labor were to be provided by the beneficiaries and if the borehole were to be fitted with a locally made hand pump. The very same borehole drilled by means of a mechanized rig and equipped the same as the first case would cost $\$ 5000$ to $\$ 7000$. Time-wise, the whole process would take 2-4 weeks in the case of the manual method, and less than a week in the case of the mechanized rig.

These estimates are also in agreement with the literature. Manual borehole is, on average, 4 to 10 times cheaper than a mechanized borehole of the same depth [44]. Based on experience from various countries, this source calculates the cost of a 30 meter mechanized borehole to be between $\$ 5000$ and $\$ 15,000$, while an average cost of $\$ 100$ to $\$ 2500$ is quoted for manual boreholes. In addition, the initial investment for manual drilling is considerably lower than for mechanized drilling equipment, which also contributes to a lower amortization cost per borehole. 
A further positive aspect of manual drilling in development contexts is that it promotes local-scale employment and income generation. This is not only true of the beneficiaries, who may make economic use of water, but also of those people who drill the borehole directly and of local craftspeople. Therefore it provides an added socioeconomic value.

Physical accessibility is often listed among the advantages of manual drilling. By maximizing the use of local resources, manual boreholes may be drilled in areas that are hardly accessible for a mechanized rig. The experience of Ghana, Democratic Republic of Congo, Zambia, Chad and Sierra Leone demonstrates that manual drilling is a valid alternative in remote regions with poor or seasonal road access, as well as in islands and areas subject to security concerns [14,50].

On the minus side, manual drilling is less versatile than mechanized drilling. More specifically, manual drilling is more constrained by geological and hydrogeological variables. All manual drilling techniques are suited to fine-grained unconsolidated sediments, where it is possible to drill at a rate of several $\mathrm{m}$ per hour. As the substrate gets harder, however, some techniques become inappropriate. For instance, only percussion-based methods can drill through indurated materials such as laterite, limestone and sandstone, even if the drilling speed slows down to just a few centimeters per day. In fresh crystalline rocks, manual drilling is generally impractical or is outright unfeasible. All this means that terrain hardness and water table depth translate into time, cost and the potential to encounter unexpected difficulties. Therefore, manual drilling is best suited to alluvial sediments, weathered materials and relatively soft indurated rocks, as well as to moderately deep water tables. If the geology is favorable, and of it is provided that drilling time is not a major concern, a realistic depth range for manual boreholes would be in the order of $25-50 \mathrm{~m}$. At these depths, manual drilling can be genuinely competitive with mechanized rigs, rendering similar outcomes at a fraction of the cost.

\subsection{Manual Boreholes Versus Excavated Wells}

For shallower depths, it makes more sense to appraise the potential of manually drilled boreholes against that of excavated wells. It is true that excavated wells can be considerably deeper. For instance, the literature showcases examples of wells that exceeded $80 \mathrm{~m}$ as early as in the 19th Century [51]. This is, however, the exception, rather than the norm. Most excavated wells worldwide serve the purpose of capturing shallow groundwater, reaching down to about 20-30 m at most.

A major advantage of manual boreholes in relation to excavated wells is depth. In tropical, arid and semiarid environments, excavated wells are preferably dug towards the end of the dry season, largely because this moment corresponds to the worst-case hydrogeological scenario. The rationale is simple: if there is water in the well at the end of the dry season, the well should always have water. Of course, this is not always accurate. Even if extraction rates are minimal, the water table will fluctuate differently each year. Thus, the above assumption only holds true if the well is drilled during a particularly adverse dry season. Furthermore, a nearby borehole or generalized aquifer overdraft may cause the well to dry up sporadically or permanently.

Manual boreholes often reach greater depths. This is because manual drilling methods are not limited to the point when the water accumulate at the bottom of the hole makes it too difficult to keep digging, and it means that manual boreholes may extend many meters below the water table. Unlike many wells, manual boreholes are unlikely to run out of water during the dry season. Greater depth also means that greater protection, as the unsaturated zone acts as a natural filter for organic and inorganic contaminants. This represents an important advantage over excavated wells, where contamination is often an issue [52-54].

A different degree of know-how is needed to drill a manual borehole than to dig an excavated well and fit it with a water-lifting device. Manual drilling is generally safer than both during the construction stage, mostly because the crew works outside the hole and needs not to worry about potential collapse of the walls, dropping objects or oxygen-related hazards.

In every other respect, considerations such as purpose, cost, maintenance and water quality will determine the most appropriate solution. For the purpose of the ensuing paragraphs, a distinction 
must be made between protected and unprotected excavated wells. Both are made by means of pick and shovel or with an excavator, but the complexity of the process differs. An unprotected well is a simple hole in the ground, large enough to accommodate the diggers and deep enough to reach the water table, whereas a protected well is normally wider and deeper, lined with bricks or pre-cast concrete and equipped with a lid, a protection wall at the surface, a sanitary seal and a gravel filter at the bottom. This is the reason why protected wells qualify as improved water sources-their waters are theoretically safe to drink-while unprotected wells do not $[53,55,56]$. It also means that protected wells require a greater degree of technical expertise and are comparatively more expensive. In the developing world, a protected well typically costs between $\$ 2500$ and $\$ 8000$ [44], while an unprotected one will not normally exceed a few hundred dollars.

The solution of choice will be case-specific and will depend on variables such as intended use, yield, water quality and cost. Again, this is best explained with examples. Consider the case of a small-size communal agricultural plot in a rural village with no resources to drill a mechanized borehole. Water quality is not as important in irrigation as it is in domestic sources, so protection may not be the most relevant issue. Yield is, however, crucial. Hence, the choice may come down to an unprotected well or a manual borehole. Once built, a large diameter well can accommodate several people around it simultaneously. Assuming a reasonably shallow water table (and a sufficiently productive well), each person can extract one 20-liter bucket per minute. This amounts to a joint yield of about $3 \mathrm{~m}^{3} / \mathrm{h}$. To exceed this flow rate, a manually drilled borehole of a similar depth would need to be wide enough to accommodate a powered pump. Fitting a pump implies a greater up-front investment (which may or may not be affordable), but, more importantly, raises the issue of maintenance.

In general, the more complex the equipment, the more reliant it can be expected to be on outside support. By choosing a powered pump, this community would automatically become dependent on external repairs and replacements. Since a broken pump results in an unusable borehole, downtimes may have catastrophic implications for the crop. All this means that a manual borehole would probably be a suboptimal choice. It may however be appropriate if the community is close to a major urban center, if it has the economic means to maintain the pump and if it is organized enough to ensure the sustainability of the scheme.

Consider now the case of a small rural community in need of a public drinking source. Water quality is much more important in this context, so an unprotected well would be out of the question. The choice in this case comes down to a manual borehole or a protected well. The former can be expected to be cheaper on average. In addition, it can reach greater depths, thus guaranteeing water during the dry season, and may yield enough water for everyone if equipped with a commercial hand pump. Maintenance concerns are less important if the hand pumps can be repaired locally [57]. In this case, a manual borehole could provide a lasting solution.

\section{Manual Boreholes: Successes and Challenges}

Manual drilling loosely falls under the umbrella of appropriate technologies, as there are different levels at which the end users may choose to do things by themselves or rely on third parties. Experience shows that non-experts can learn to drill manual boreholes, particularly if the hydrogeological conditions are favorable. This is one of the main reasons why the technology has been picked up by individuals and communities, with hundreds of thousands of boreholes drilled all over the world without direct professional advice. From this perspective, manual drilling may contribute to the fulfilment of several of the Sustainable Development Goals, including Goal number 6: "ensure access to water and sanitation for all". This is particularly likely to happen if manual drilling is embraced by the private sector (i.e., if there is a market willing to pay). Take, for instance, the cases of Bangladesh, Chad, India and Madagascar, where thousands of households own manual boreholes. Nevertheless, perhaps the most interesting case is that of Nigeria. In this country, hundreds of small-scale hand-drilling enterprises are currently operational, employing thousands of people. Manually drilled boreholes supply water to five million people across Lagos state, either directly or through street vendors, which leads [17] 
to conclude that manual drilling has been proven to be a good opportunity for middle class families to obtain water on the household scale. Thus, the Lagos experience shows that hand drilling has the potential to go viral if the setting is right.

However, a successful borehole is not only the result of learning a drilling technique. Finding groundwater, avoiding contamination and protecting the borehole is vital to ensure good-quality water supplies in the long run. Learning how to drill is relatively easy, and the investment required to set up a drilling enterprise is small. This, coupled with the lack of knowledge of what constitutes a good quality borehole by the client, means that there is a high risk of poor quality workmanship, and even the potential to contaminate aquifers.

The Nigerian case shows that many professional drillers do not have formal training, possibly due to the ease with which the basics of the technique can be learned. Many do not know the borehole construction regulations, nor do they carry out routine quality assurance. This could end up threatening their business model in the mid- to long-term. Take, for instance, the case of Chad, where a country-scale assessment found that early failures in sustainable supply maintenance led to a negative perception of the effectiveness of manual boreholes on the part of users and water authorities [57]. Common causes of borehole malfunction included inadequate attention to borehole design, poor material choices, inadequate construction practices, the absence of hydrogeological knowledge (leading to inadequate siting and borehole contamination) and a lack of accountability.

Studies dealing specifically with the contamination of manual boreholes are rare. However, the way this technology has taken off in some countries suggests that contamination could become a problem. Much like domestic wells and mechanized boreholes, manual boreholes are routinely drilled with little regard for the presence of sewers, latrines and other contamination sources. This, together with the absence of water treatment and water quality monitoring, puts domestic supplies in jeopardy, and calls for strategies to ensure that manual boreholes actually provide safe water. In this context, a potentially useful course of action could be to raise awareness among users as to the need to carry out routine water quality tests.

Early warning signs tend to be overlooked by the population. For instance, a large share of the people served by self-supply boreholes in Lagos does not yet anticipate problems of groundwater overdraft despite falling water tables in some sectors [58]. Furthermore, only a small fraction considers that groundwater contamination could pose a threat in the future. This explains why government officials from certain countries fear that the proliferation of self-made boreholes can turn into a threat to the integrity of groundwater resources [59].

Manual drilling provides most of its added value during the construction stage. This means that, per se, it does not tackle the upkeep problems that have become so frequent in communal water sources across Sub-Saharan Africa [34]. However, it is also true that the potential to equip manual boreholes with locally made pumps adds to the sense of appropriation on the part of local communities, and that it reduces reliance on outside inputs. Both these features empower users and facilitate the development of operation and maintenance strategies.

Ultimately, the challenges faced by manual drilling may be considered as growing pains. Potential solutions include raising the profile of the technique among citizens and water authorities and setting up formal training institutions and construction standards, as well as strengthening regulatory frameworks and establishing accountability mechanisms for drillers to respond before the water authorities.

\section{Conclusions}

Well into the 21st Century, water access remains an everyday challenge for many people in low income countries. This is particularly true of rural areas, where piped connections at the household level are uncommon and where primarily women and children haul water over long distances. Aquifers have the potential to mitigate these problems by providing a reliable and plentiful supply of good quality water. Unfortunately, improved groundwater sources such as mechanized boreholes are often unaffordable for end users, and expensive for development agencies. 
While not exempt from shortcomings, manual drilling may contribute to mitigating the problem of water access in many such contexts. This paper has appraised the pros and cons of this technology. It is concluded that manual boreholes present significant advantages, including cost effectiveness, high appropriation potential, labor-intensiveness, local income generation and local control. Manual boreholes thus provide a competitive solution under a relatively wide variety of settings, ranging from rural communities to middle class households. From the geological standpoint, manual drilling has the potential to excel in unconsolidated materials and at moderate depths, particularly if modest flow rates are acceptable. On the other hand, experience also shows that there is a need to harness the potential of manual drilling in those contexts where it has grown to become widespread. This entails supporting the introduction of the technology, the design of quality control mechanisms, business development and the professionalization of the sector.

Because water plays a part in everyone's life, owning a manually drilled borehole can trigger important changes to the dynamics of individuals, families and communities. Taking cultural factors into consideration is crucial to ensure a smooth social transition in contexts where manual drilling is promoted by external organizations. These will always need to consider the sanitary conditions when designing and installing water supply systems, as the goal is to provide accessible infrastructures that are respectful to social and cultural values, as well as to ensure adequate collection, treatment and disposal of wastewater.

Author Contributions: Conceptualization, P.M.-S., M.M.-L., K.D. and S.D.-A.; formal analysis, K.D. and P.M.-S.; supervision, M.M.-L. and S.D.-A.; project administration, P.M.-S.; All authors have read and agreed to the published version of the manuscript.

Funding: This research has been funded by the Agencia Española de Cooperación al Desarrollo (AECID), under grant numbers 2016/ACDE/001953 and 2018/ACDE/0799.

Conflicts of Interest: The authors declare no conflict of interest. The funders had no role in the design of the study; in the collection, analyses, or interpretation of data; in the writing of the manuscript, or in the decision to publish the results.

\section{References}

1. United Nations. Resolution A/RES/64/292; United Nations General Assembly: New York, NY, USA, 2010.

2. World Health Organization. Safely Managed Drinking Water-Thematic Report on Drinking Water; World Health Organization: Geneva, Switzerland, 2017.

3. Pattnaik, B.K.; Dhal, D. Mobilizing from appropriate technologies to sustainable technologies based on grassroots innovations. Technol. Soc. 2015, 40, 93-110. [CrossRef]

4. Kruger, P. Appropriate technologies for large-scale production of electricity and hydrogen fuel. Int. J. Hydrogen Energy 2008, 33, 5881-5886. [CrossRef]

5. Martí-Herrero, J.; Chipana, M.; Cuevas, C.; Paco, G.; Serrano, V.; Zymla, B.; Heising, K.; Sologuren, J.; Gamarra, A. Low cost tubular digesters as appropriate technology for widespread application: Results and lessons learned from Bolivia. Renew. Energy 2014, 71, 156-165. [CrossRef]

6. Murphy, H.M.; McBean, E.A.; Farahbakhsh, K. Appropriate technology-A comprehensive approach for water and sanitation in the developing world. Technol. Soc. 2009, 31, 158-167. [CrossRef]

7. Helweg, O.J.; Smith, G. Appropriate Technology for Artificial Aquifers. Ground Water 1998, 16, 144-148. [CrossRef]

8. Chigerwe, J.; Manjengwa, N.; Van Der Zaag, P.; Zhakata, W.; Rockström, J. Low head drip irrigation kits and treadle pumps for smallholder farmers in Zimbabwe: A technical evaluation based on laboratory tests. Phys. Chem. Earth 2004, 29, 1049-1059. [CrossRef]

9. Skinner, B.; Shaw, R. VLOM Pumps-Technical Brief 41; Loughborough University: Loughborough, UK, 1999.

10. Adekile, D.; Olabode, O. Hand Drilling in Nigeria. Why Kill an Ant with a Sledgehammer? Rural Water Supply Network, UNICEF: Field Note No 2009-1; United Nations International Children's Emergency Fund (UNICEF): New York, NY, USA, 2009; 12p.

11. Bowman, I. Well Drilling Methods. United States Geological Survey; Department of the Interior: Washington, DC, USA, 1911; p. 134. 
12. Danert, K. Realizing the potential of hand-drilled wells for rural water supplies. Waterlines 2009, 28, 108-129. [CrossRef]

13. Tolman, C.F. Ground Water; McGraw Hill: New York, NY, USA; London, UK, 1937; p. 593.

14. Danert, K. Manual Drilling Compendium Rural Water Supply Network; Skat: St Gallen, Switzerland, $2015 ;$ p. 40.

15. UNICEF. Capitalisation D'experiences sur les Forages Manuels à Madagascar; Technical Report, Practica Foundation; United Nations International Children's Emergency Fund (UNICEF): New York, NY, USA, 2012; p. 50.

16. Kane, C.H.; Danert, K. Manual Drilling in the Democratic Republic of Congo: Reaching the Tipping Point within a Decade; Technical Report; Rural Water Supply Network (RWSN): St. Gallen, Switzerland, 2020.

17. Danert, K.; Adelike, D.; Gesti-Canuto, J. Manually Drilled Boreholes: Providing Water in Nigeria's Megacity of Lagos and Beyond; Skat Foundatio: Gallen, Switzerland, 2019; Available online: https://www.rural-watersupply.net/en/resources/details/618 (accessed on 15 December 2019).

18. Weight, E.; Yoder, R.; Keller, A. Manual Well Drilling Investment Opportunity in ETHIOPIA. COLOMBO, Sri Lanka: International Water Management Institute (IWMI); IWMI Working Paper 155; IWMI: Colombo, Sri Lanka, 2013. [CrossRef]

19. Martínez-Santos, P.; Martín-Loeches, M.; Solera, D.; Cano, B.; Díaz-Alcaide, S. Mapping the Viability, Time, and Cost of Manual Borehole Drilling in Developing Regions. Water 2017, 9, 262. [CrossRef]

20. UNICEF-WHO. Progress on Drinking Water and Sanitation; United Nations International Children's Emergency Fund-World Health Organization (UNICEF-WHO): New York, NY, USA, 2012.

21. UNICEF-WHO. Progress on Sanitation and Drinking Water-2015 Update and MDG Assessment; United Nations International Children's Emergency Fund-World Health Organization (UNICEF-WHO): New York, NY, USA, 2015.

22. Martínez-Santos, P. Does $91 \%$ of the world's population really have "sustainable access to safe drinking water"? Int. J. Water Resour. Dev. 2017, 33, 514-533. [CrossRef]

23. Misati, A.G.; Ogendi, G.; Peletz, R.; Khush, R.; Kumpel, E. Can sanitary surveys replace water quality testing? Evidence from Kisii, Kenya. Int. J Environ. Res. Public Health 2017, 14, 152. [CrossRef]

24. Shaheed, A.; Orgill, J.; Montgomery, M.A.; Jeuland, M.A.; Brown, J. Why 'Improved' Water Sources are not always Safe; Bulletin of the World Health Organization: Geneva, Switzerland, 2014; Volume 92, pp. 283-289.

25. UNICEF-WHO. Safely Managed Drinking Water-Thematic Report on Drinking Water; United Nations International Children's Emergency Fund-World Health Organization (UNICEF-WHO): New York, NY, USA, 2017.

26. World Bank. World Bank Data. Available online: http://data.worldbank.org/ (accessed on 22 May 2018).

27. Delaire, C.; Peletz, R.; Kumpel, E.; Kisiangani, J.; Bain, R.; Khush, R. How Much Will It Cost To Monitor Microbial Drinking Water Quality in Sub-Saharan Africa? Environ. Sci. Technol. 2017. [CrossRef] [PubMed]

28. Lilje, J.; Mosler, H.J. Continuation of health behaviors: Psychosocial factors sustaining drinking water chlorination in a longitudinal study from Chad. Sustainability 2016, 8, 1149. [CrossRef]

29. Ndé-Tchoupé, A.I.; Crane, R.A.; Mwakabona, H.T.; Noubactep, C.; Njau, K.N. Technologies for decentralized fluoride removal: Testing metallic iron based filters. Water 2015, 7, 6750-6774. [CrossRef]

30. Grönwall, J.; Danert, K. Regarding Groundwater and Drinking Water Access through A Human Rights Lens: Self-Supply as A Norm. Water 2020, 12, 419. [CrossRef]

31. Zekster, I.S.; Everett, L.G. Groundwater Resources of the World and Their Use; UNESCO IHP-VI Series on Groundwater. No. 6. Paris; UNESCO: New York, NY, USA, 2004; p. 342.

32. Girma, M.; Assefa, A.; Molinas, M. Feasibility study of a solar photovoltaic water pumping system for rural Ethiopia. Environ. Sci. 2015, 2, 697-717. [CrossRef]

33. Yorkor, B.; Leton, T.G. Solar water supply for rural communities in Rivers State, Niger Delta of Nigeria. IJEES 2017, 5, 1-17.

34. The Rural Water Supply Network Executive Steering Committee. Myths of the Rural Water Supply Sector; RWSN: St. Gallen, Switzerland, 2010.

35. Foster, T. Predictors of sustainability for community-managed hand pumps in Sub-Saharan Africa: Evidence from Liberia, Sierra Leone, and Uganda. Environ. Sci. Technol. 2013, 47, 12037-12046. [CrossRef]

36. Liddle, E.S.; Fenner, R. Review of Handpump-Borehole Implementation in Uganda; British Geological Survey: Nottingham, UK, 2018. 
37. Danert, K. (Ask for Water, Madrid, Spain) Manual drilling around the world. Seminar of the UNESCO Chair “Appropriate Technologies for Human Development" on Manual Drilling. Oral presentation. 2019.

38. Danert, K.; Carter, R.C.; Adekile, D.; MacDonald, A. Cost-effective boreholes in sub-Saharan Africa. In Proceedings of the 33rd WEDC International Conference, Accra, Ghana, 7-11 April 2008.

39. World Bank. Etude Sur l'optimisation du cô̂t des Forages en Afrique de l'Ouest. Rapport de Synthèse; Rapport $n$ 44743/A; World Bank: Orléans, France, 2007.

40. Van-Kinderen, I.; Vuik, R.; Pelgrim-Adams, A. From emergency to development or viceversa? Key lessons from the innovation of a well-drilling method. In Water Sanitation and Hygiene Services Beyond 2015: Improving Access and Sustainability, Proceedings of the 38th International Conference, Loughboroug, UK, 27-31 July 2015; IWMI: Colombo, Sri Lanka, 2015.

41. Carter, R.C. Human-Powered Drilling Technologies: An Overview of Human-Powered Drilling Technologies for Shallow Small Diameter Well Construction, for Domestic and Agricultural Water Supply; Technical Report; Cranfield University: Bedfordshire, UK, 2005; p. 18.

42. Tapia Reed, D. Perforación Manual de Pozos Profundos Usando el Método EMAS-AYNI.; Technical Report; Universidad Técnica Federico Santa María: Valparaíso, Chile, 2008; p. 79.

43. Waller, T.; (Water For All International, San Angelo, TX, USA). Personal communication, 2015.

44. Practica Foundation. Sludging. Manual Drilling Series. Technical Training Handbook on Affordable Manual Well Drilling; Practica Foundation: Papendrecht, The Netherlands, 2011; p. 88.

45. Martínez-Santos, P. Determinants for water consumption from improved sources in villages of southern Mali. Appl. Geogr. 2017. [CrossRef]

46. Grönwall, J.; Oduro-Kwarteng, S. Groundwater as a strategic resource for improved resilience: A case study from peri-urban Accra. Environ. Earth Sci. 2018, 77, 6. [CrossRef]

47. Fussi, F.; Fumagalli, L.; Fava, F.; Di Mauro, B.; Hamidou, C.; Kane, M.; Souleye, N.; Wade, S.; Hamidou, B.; Colombo, R.; et al. Classifying zones of suitability for manual drilling using textural and hydraulic parameters of shallow aquifers: A case study in northwestern Senegal. Hydrogeol. J. 2017, 25, 2263-2279. [CrossRef]

48. Solera, D.; Cano, B. Cartografía de Zonas Susceptibles de Perforación Manual con el Método Baptista en los Acuíferos de Zócalo del Sector Siby-Bancoumana-Narena (sur de Mali). Posgrado de Especialización en Agua, Saneamiento e Higiene en Cooperación Internacional. Master's Thesis, Universidad de Alcalá, Madrid, Spain, 2017.

49. AECID. Experiencias de Perforación Manual Para el Abaratamiento Del Acceso al Agua en la República de Mali; Technical Report; Agencia Española de Cooperación Internacional al Desarrollo: Madrid, Spain, 2017; p. 81. ISBN 978-84-617-8426-4.

50. Naugle, J.; Hangen, M.; Brubacher, C. Examples of Manual Drilling in Remote, or Difficult to Serve Areas. Hand Drilling Cluster Group. Available online: https:/dgroups.org/rwsn/groundwater/handdrilling/ discussions (accessed on 15 December 2019).

51. Kent, B. Hand-Dug Water Wells: A Vanishing Technology. In Proceedings of the Colloque International OH2 Origines et Histoire de l'Hydrologie, Dijon, France, 9-11 May 2001; Available online: https://www.pseau.org/ outils/ouvrages/iahs_hand_dug_water_wells_a_vanishing_technology_2001.pdf (accessed on 15 December 2019).

52. Liddle, E.S.; Mager, S.M.; Nel, E.L. The suitability of shallow hand dug wells for safe water provision in sub-Saharan Africa: Lessons from Ndola, Zambia. Appl. Geogr. 2015, 57, 80-90. [CrossRef]

53. Martínez-Santos, P.; Martín-Loeches, M.; García-Castro, N.; Solera, D.; Díaz-Alcaide, S.; Montero, E.; García-Rincón, J. A survey of domestic wells and pit latrines in rural settlements of Mali: Implications of on-site sanitation on the quality of water supplies. Int. J. Hyg. Environ. Health. 2017, 220, 1179-1189. [CrossRef] [PubMed]

54. Wanke, H.; Nakwafila, A.; Hamutoko, J.T.; Lohe, C.; Neumbo, F.; Petrus, I.; David, A.; Beukes, H.; Masule, N.; Quinger, M. Hand dug wells in Namibia: An underestimated water source or a threat to human health? Phys. Chem. Earth 2014, 76-78, 104-113. [CrossRef]

55. United Nations International Children's Emergency Fund. The rights to safe water and to sanitation. Curr. Issues 2014, 3, 1-5.

56. Martínez-Santos, P.; Cerván, J.A.; Cano, B.; Díaz-Alcaide, S. Water versus Wireless Coverage in Rural Mali: Links and Paradoxes. Water 2017, 9, 375. [CrossRef] 
57. Practica Foundation. The Impact of Manual Drilling for the Construction of Sustainable Water-Points in Chad. Fact Sheet. 59; Practica Foundation: Madagascar, The Netherland, 2009; Volume 12.

58. Capstick, S.; Whitmarsh, L.; Healy, A.; Bristow, G. Resilience in Groundwater Supply Systems: Findings from a Survey of Private Households in Lagos, Nigeria; RIGSS Working Paper; RIGSS: Phuentsholing, Bhutan, 2017.

59. Jabbi, H.; (Department of Water Resources of the Gambia, Banjul, The Gambia). Personal communication, March 2017.

(C) (2)

(C) 2020 by the authors. Licensee MDPI, Basel, Switzerland. This article is an open access article distributed under the terms and conditions of the Creative Commons Attribution (CC BY) license (http://creativecommons.org/licenses/by/4.0/). 